\title{
NOTES ON SOME PSEUDOTHELPHUSIDAE CRABS FROM VENEZUELA, ECUADOR AND MEXICO FOUND IN THE COLLECTION OF THE MUSEU DE ZOOLOGIA DA UNIVERSIDADE DE SÃO PAULO, SÃO PAULO, BRAZIL
}

Célio Magalhães *

\begin{abstract}
This note reports on three species of Pseudothelphusidae crabs, Microthelphusa simoni from Venezuela, Hypolobocera rathbuni from Ecuador and Epithelphusa chiapensis from Mexico, that were found in the collection of the Museu de Zoologia da Universidade de Säo Paulo. Illustrations of the gonopods are given.

\section{INTRODUCTION}

During a study of the Brazilian freshwater crabs carried out at the "Forschungsinstitut Senckenberg" (Frankfurt a.M., West Germany) in January-February 1985, species strange to the Brazilian fauna were found in three lots. These lots are part of the "Museu de Zoologia da Universidade de São Paulo"(MZUSP)'s collection that was borrowed especially for this investigation. The purpose of this paper is to inform of the presence of these species in the MZUSP's collection, illustrate the gonopods and comment the specimens. The terminology used is the same as that of Smalley (1964) and Rodríguez (1982) for the gonopod structures, although for naming their surfaces I employed the real orientation in the abdomen. The measurements were taken in millimiters and correspond to carapace breadth: carapace length: body heigth: frontal breadth.

More detailed descriptions of these species as well as information on their relationships and zoogeographical distribution have been given by Rathbun (1905), Pretzmann (1968), Rodríguez (1966; 1982) and Rodríguez \& Smalley (1969).

I am indebted to Dr. Paulo E. Vanzolini, Dr. Gustavo A.S. de Melo (MZUSP), Dr. Wolfgang Junk (Max-Planck Institut für Limnologie), Dr. Michael Türkay (Forschungsinstitut Senckenberg) and Dr. Bárbara Robertson (INPA) for their help in different phases of this work; I also thank the "Max-Planck Gesellschaft" for the grant that allowed the study period in West Germany.
\end{abstract}

Neopseudothelphusa simoni (Rathbun, 1905)

Pseudothelphusa simoni Rathbun, 1905, p. 291.

Neopseudothelphusa simoni, Rodríguez, 1982, p. 167-168, fig. 117 (a-d).

Material: Venezuela, Estado de Miranda, Parque Nacional Guatopo, $750 \mathrm{~m}$, under a decayed tree trunk, I male (MZUSP 6388), C.R. Brandão coll.

* Instituto Nacional de Pesquisas da Amazônia; Depto. de Biologia Aquática e Limnologia, Caixa Postal 478 - 69.000 - Manaus, AM - Brasil. 
Measurements: $40.5: 24.9: 16.8: 11.5$

The specimem agrees quite well with Rodríguez's (1982) description, although it does not present the upper frontal ridge with a very distinct row of tubercules as figured by Rodríguez (1966, pl. 3, fig. 3). The tubercules, while present, are somewhat coalescent. The chelipeds are unequal, the right one being larger and having a swollen palm.

The margin of the gonopod (Figs. 1;2) is situated on the mesial surface, turning towards the caudal side at the distal end; the subterminal marginal process is produced, latero-terminally, beyond the border of the distal portion of the stem. The mesial process is similar to an acute triangle, well separated fiom the short apical plate. The lateral surface is somewhat concave and oblique, with a bent apex. The spine field is situated laterally, at the base of this concave surface.

The alcohol preserved specimen has a gray carapace, that is pale brown on the branchial region; the walking legs are pale brown; the chelipeds are light gray, the chelas being lighter.

This species is distributed in the mountainous region of Central Venezuela (Rodríguez, 1966). Several collections have been made in the State of Miranda (Rodríguez, 1966; Weibezahn, 1952).

\section{Hypolobocera rathbuni Pretzmann, 1968}

Hypolobocera (Hypolobocera) rathbuni Pretzmann, 1968, p. 5. Hypolobocera rathbuni, Rodríguez, 1982, p. 63, fig. 34 (a-c).

Material: Ecuador, Pichincha, $10 \mathrm{~km}$ south from Santo Domingo de los Colorados, 3 males (2 juveniles), (MZUSP 6383), P.E. Vanzolini coll., Nov. 15, 1980.

Measurements: $36.8: 23.8: 14.3: 10.4 ; 17.7: 11.9: 6.95: 5.5 ; 14.8: 10.6: 5.0$ : 4.8

The lateral margin of the carapace has a conspicuous notch behind the orbit, followed by two or three ill-defined teeth up to the end of the cervical groove and 13 to 17 small acute teeth that become smaller and blunt posteriorly. The median groove is distinct in the adult, separating the small post-frontal lobes by a moderately deep incision. The upper margin of the front shows an incision in the middle, visible even in the juveniles; the lower margin is marginate, showing some faint tubercules; the space between both margins is greater in the center.

I did not distinguish the finely granulated carapace described by Pretzmann (1968) in the adult, although in the juveniles this character is quite visible, particulary in the anterior and branchial regions.

The gonopod (Figs. $3 ; 4$ ) agrees exactly with that illustrated by Pretzmann (1972, p. 64, fig. $34 \mathrm{a}-\mathrm{c}$ ). It has an elongated but shallow lateral lobe and a strong crest along the caudal surface. The spine field is in a distal position. In apical view, the contour of the gonopod is roughly oval, with a slender apex pointing laterally.

The adult specimen exhibits a brown coloration in the carapace, except in the branchian region where the colour is lighter; the juveniles are light brown.

Rodrígues (1982) verified that the holotype of this species has disappeared from the British Museum and proposed as neotype a male from Santo Domingo, which is located $160 \mathrm{~km}$ south from the type locality, but in the same mountain range. The material examined here was collected near the neotype locality. 

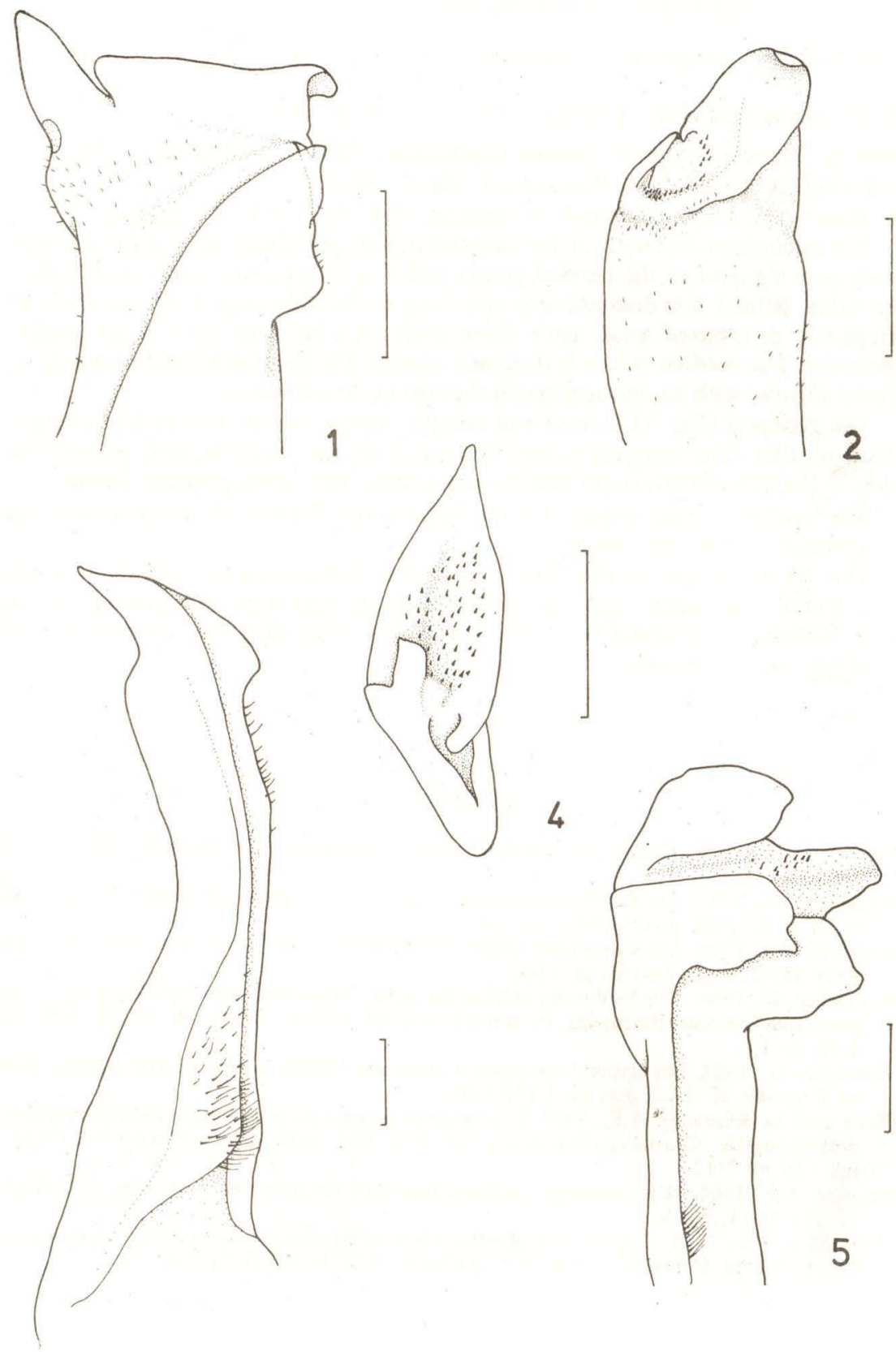

Figures 1-5 - Microthelphusa simoni, left gonopod: 1 - Mesial view. 2 - Lateral view. Hy. polobocera rathbuni, right gonopod: 3 - Caudal view. 4 - Apical view. Epithelphusa chiapensis, right gonopod: 5 - Mesial view. (Scale lines $=1 \mathrm{~mm}$ ). 


\section{Epithelphusa chiapensis (Rodríguez \& Smalley, 1969)}

Spirothelphusa chiapensis Rodríguez \& Smalley, 1969, p.p. 75, figs. 6 (a-e); 25e, pl. 3.

Epithelphusa chiapensis, Rodríguez, 1982, p. 128, fig. $83(\mathrm{a}-\mathrm{e})$.

Material: Mexico, State of Chiapas, Montozintla, Finca de la Victoria, 1 male, 1 female (MZUSP 6380), M.A. Vulcano coll. May 6, 1962.

Measurements: $18.0: 11.3: 6.4: 5.8$ (male); $27.4: 15.6: 9.4: 7.8$ (female).

The anterolateral margin of the carapace in both specimens has a slight discontinuity near the end of the cervical groove and 7 to 8 very small, blunt teeth behind the orbit. Behind this discontinuity and along the lateral margin there are 18 to 22 irregularly distributed small teeth; these teeth are a bit more acute in the smaller specimen. The median sulcus is deep and narrow. The front is divided medianly by a deep furrow, with an uniform heigth throughout its extension.

The gonopod (Fig. 5) is short and straight, with a narrow stem and an enlarged distal portion. The marginal process is situated on the mesial surface, perpendicularly to the axis of the margin and showing a small tooth at its proximal border.

The female carapace is gray and the legs are light brown; the carapace and legs of the male are also light brown.

This species occurs in the State of Chiapas, Mexico and the specimens which were studied here come from the same place as the type series (Montozintla, Finca de la Victoria). This seems to be the only report, other than the holotype and the paratype, for this species.

\section{REFERENCES}

Pretzmann, G., 1968. Neue südamerikanische Süsswasserkrabben. Ent. NachrBl., Wien, 15 (1): 1-15.

Pretzmann, G., 1982. Die Pseudothelphusidae (Crustacea Brachyura). Zoologica, Stuttgart, 42 (120) pt. 1:1-182, text-fig. 1-31, pl-fig. 1-732.

Rathbun, M.J., 1905. Les crabes d'eau douce (Potamonidae). Nouv. Arch. Mus. Hist. nat. Paris, 4 (7): 159-321, fig. 38-105, pl. 13-22.

Rodríguez, G., 1966. The freshwater crabs of the genus Pseudothelphusa from Northern Venezuela and Trinidad (Brachyura, Potamonidae). Zool. Meded., Leiden, 41 (6): 111-135, fig. 1-10, pl. 1-7.

Rodrigues, G., 1982. Les crabes d'eau douce d'Amerique. Famille des Pseudothelphusidae. Faune Tropicale, 22: 1-22, text-fig. 1-132, I tab.

Rodríguez, G. \& Smalley, A.E., 1969. Los cangrejos de agua dulce de México de la familia Pseudothelphusidae (Crustacea, Brachyura). An. Inst. Biol. Univ. Autón. México, 40: 69-112, fig. 1-26, pl. 1-12.

Smalley, A.E., 1964. A terminology for the gonopods of the American river crabs. Syst. Zool., 13. (1): 28-31, fig. 1 .

Weibezahn, F.H., 1952. Contribución al estudio de los cangrejos dulceanuicolas de la region Baruta-El Hatillo. Mems. Soc. Cienc. nat. "La Salle", 12 (31):67-70, fig. 1-3. 